\title{
Lærebokas makt: En studie av lærebøker for instrumentalelever
}

\author{
Hilde Synnøve Blix \\ UiT - Norges arktiske universitet
}

\begin{abstract}
Sammendrag
Denne artikkelen bygger på en studie av lærebøker for nybegynnere på et musikkinstrument. Målet med studien var å undersøke de mest brukte instrumentallærebøkene i Norge i et Freireinspirert kritisk pedagogisk perspektiv. I studien analyseres innholdet i 26 lærebøker for 15 forskjellige instrumenter. Analysen tar utgangspunkt i et kritisk pedagogisk perspektiv på lærebøkenes faglige innhold og oppgavetyper, med vekt på hvordan dialog, makt og utvikling av kritisk bevissthet utspiller seg. Studien viser at de mest brukte lærebøkene er nokså like i utforming, innhold og i måten de presenterer lærestoffet på. Oppgavetypene i bøkene er i stor grad øve- og kontrolloppgaver, og man ser i liten grad oppgaver som oppfordrer til kritisk og kreativ tenkning. Selv om mange av bøkene har som eksplisitt mål å ta utgangspunkt i elevens musikalske verden, er det lite vekt på dette i bøkenes konkrete metodikk. Det kritisk pedagogiske perspektivet analysen er basert på, viser at lærebøkene ikke alltid lykkes med å formidle en bevisstgjørende, dialogisk pedagogikk, noe som også forteller at det er behov for mer forskningsbasert kunnskap om instrumentallærebøker og hvordan de brukes i undervisning. I og med dagens teknologi og barns bruk av nettressurser for å lære, er det også nødvendig å spørre seg hva framtidens læremateriell kan og bør være.
\end{abstract}

\section{Nøkkelord: Larebøker; notekyndighet; kulturskole; musikkpedagogikk; larebokanalyse}

\begin{abstract}
This article is based on a study of musical instrument textbooks for beginners. The aim of the study was to investigate the most commonly used music textbooks in Norway through the perspective of Freirian critical pedagogy. The study analyses the content and exercises of 26 textbooks for 15 different instruments in light of the concepts of dialogue, power, and critical thinking. The study shows that the frequently used textbooks are rather similar in layout, content, and in the ways in which they present the teaching material. The exercises are mainly geared towards techniques of practice or control, with very few tasks designed to facilitate critical and creative thinking. Even though many of the books state explicit goals regarding communication and the student's musical experience, the study revealed that there are in fact few concrete examples of dialogic pedagogy in the books. The Freirian perspective used in the analysis, suggests that music textbooks for beginners do not achieve their stated objectives in their own stated aims, and that there is a need for more studies investigating the use of textbooks in music education. It is also vital that future studies look at the possibilities that lie in today's technology when developing future learning recourses.
\end{abstract}

\footnotetext{
^Korrespondanse: Hilde Synnøve Blix, UiT Norges arktiske universitet, Postboks 6050 Langnes, 9037 Tromsø. Epost: hilde.blix@uit.no
}

(C) 2018 H. S. Blix. This is an Open Access article distributed under the terms of the Creative Commons Attribution 4.0 International License (https://creativecommons.org/licenses/by-nc/4.0/), allowing third parties to copy and redistribute the material in any medium or format and to remix, transform, and build upon the material for any purpose, even commercially, provided the original work is properly cited and states its license.

Citation: H. S. Blix. «Larebokas makt: En studie av larebøker for instrumentalelever». Fournal for Research in Arts and Sports Education, Special Issue: "Skapende og tenkende - Perspektiver på kritisk kunstpedagogikk i skole og kulturliv" 
Keywords: Textbooks; textbook analysis; music pedagogy; music literacy

Received: June, 2017; Accepted: May, 2018; Published: July, 2018

Lareren: $\quad$ Fikk ikke du en bok av meg?

Eleven: $\quad$ fo.

Lareren: $\quad H v o r$ tror du den er henne? Ligger den hjemme?

Eleven: $\quad f a$.

Lareren: $\quad$ (ler) fa, den må du ha med på timen.

Eleven: Må jeg?

Lareren: $\quad \exists a$, det må du, ellers så vet vi jo ikke hva du skulle ha spilt på (...). Den må du ha med neste gang, så vi har noe å spille etter.

(Blix, 2012, s. 119)

\section{Innledning}

Lærebøker representerer et vesentlig element i undervisningen i kulturskolenes instrumentalopplæring, spesielt på begynnernivå, og bidrar på mange måter til å definere både musikalsk innhold og tilnærmingsmåter til undervisning i kulturskolene. Lærebokforskning viser at lærebøker tradisjonelt har hatt stor innflytelse på måtene det undervises på i de fleste skolefag i Norge, og i neste ledd måten elevene lærer på (Askeland, Maagerø \& Aamotsbakken, 2013; Johnsen, 1993; Skjelbred, Solstad \& Aamotsbakken, 2005). Selv om andre typer læringsressurser har økt i mengde og er mer tilgjengelig enn noensinne, er lærebokas posisjon fremdeles sterk (Skjelbred \& Aamotsbakken, 2010, s. 17). Flere undersøkelser viser at dette også gjelder i undervisning av nybegynnere på musikkinstrumenter (Blix, 2012; Rostvall \& West, 2001).

Læreboka kan være en rik kilde til kunnskap og bidra til kunnskapsutvikling generelt. I musikkfaget har mange dyktige og engasjerte lærere, lærerutdannere og musikere lagt ned mye arbeid i å videreformidle sine pedagogiske refleksjoner og sin spilleglede til neste generasjon musikanter gjennom lærebøker. Tross mange gode intensjoner og etter hvert en rekke bøker å velge mellom, er det mye diskusjon rundt instrumentallærebøkenes innhold og kvalitet blant musikkpedagogene som bruker bøkene. De fleste diskusjonene går på hvorvidt bøkene fungerer for de enkelte instrumentene, valg av musikk, om de er tilpasset alderen til elevene og den metodiske tilretteleggingen i boka. I forskningssammenheng drøftes også bøkenes kunnskap- og læringssyn, estetiske relevans og bøkenes rolle i musikkundervisningen (Rønningen, 2015; Sanner, 2003).

Lærebokas sterke posisjon i undervisningen gir den potensielt stor definisjonsmakt, og i denne artikkelen vil jeg se på lærebøker for instrumentalelever på begynnernivå i lys av begreper om dialog, makt og kritisk bevissthet slik de er brukt i Freireinspirert kritisk pedagogikk. Studien er motivert av forskning som viser at undervisning i nordiske land, også i musikk, har en tendens til å være nokså læremiddelstyrt (Blix, 2012; Juhl, Hontvedt \& Skjelbred, 2010; Rostwall \& West, 2001), noe som tilsier at man bør ha god kunnskap om hva som karakteriserer gode lærebøker. Den som underviser bør ha en bevisst og kritisk reflektert holdning til både valg og bruk av lærebøker, og til hvorfor/om det er behov for lærebok i det hele tatt. Det foreligger 
i dag lite forskning som ser på instrumentallærebøker i kritisk pedagogisk lys. Studien tar utgangspunkt i spørsmålet om hvordan dimensjonene dialog, makt og kritisk bevissthet utspiller seg i lærebøker ${ }^{1}$ for instrumentalelever på begynnernivå.

Artikkelen inviterer gjennom dette til debatt om lærebokas rolle i musikkundervisningen i kulturskolen, og ser spesielt på hvordan kritisk pedagogiske perspektiver kan bidra til å skape nye innfallsvinkler til læring og undervisning i musikkfagene.

\section{Lærebokforskning}

Forskning på lærebøker undersøker i hovedsak bøkene ut fra enten intensjon, kjennetegn ved selve innholdet eller konteksten de inngår i (Selander \& Skjelbred, 2004). I mange undersøkelser analyseres bøkenes tekster og bilder med utgangspunkt i forskjellige perspektiver på kunnskap og læring. Man har også sett på hva slags forskjellige læringsressurser som brukes og hvordan de anvendes i skolen.

I motsetning til i instrumentalundervisningen er lærebøker som brukes i det offentlige skolesystemet vanligvis designet $i$ henhold til gjeldende læreplaner i de forskjellige fagene. Dette gir læreboka en potensiell rolle som fortolker av læreplanenes fag- og kunnskapssyn, og lærerne underviser ofte læreplanens innhold slik den er prioritert i læreboka (Tønnesen, 2013, s. 149). Det er også interessant å merke seg at det i skolen kan være en tendens til at lærebøkene «trumfer» læreplanen: «Som studenter i praksis har vi erfart at kompetansemålene [i læreplanen] har lavere status enn lærebøkene» (Nordlysdebatt 23.10.14). Selv om man i Norge har utarbeidet fag- og rammeplaner for kulturskolene, er disse ikke i samme grad obligatoriske og styrende for innholdet $\mathrm{i}$ instrumentalundervisningen, og vil dermed ikke ha samme innvirkning på utarbeidelse av lærebøker. Dette gir lærebokforfatterne enda større frihet, og dermed makt, som premissleverandører for instrumentalundervisning på begynnernivå.

Sanner gjennomførte i 2003 en studie av to læreverk for musikk i ungdomstrinnet og måten et utvalg lærere brukte disse bøkene. Hun fant blant annet at læreboka bidro til å øke fagets status, og at den på mange måter framsto som «et symbol på kunnskap». Hun etterlyser en epistemologisk debatt om hva kunnskap i musikkfaget kan være og hvilken posisjon læreboka bør og kan ha.

Det er gjort noen få nordiske undersøkelser av lærebøker for instrumentalelever. De fleste av disse er eldre hovedoppgaver som ser på spesifikke bøker for spesifikke instrumenter. Noen eksempler er Ødegårds analyse av sang og sangbøker i norsk skolehistorie (Ødegård, 1995), Hoffart (1995) som analyserer og sammenligner nye og gamle cellolærebøker, og Fuglseths analyse og vurdering av hornlærebøker (Fuglseth, 1994). I Sverige utkom doktoravhandlingen «Interaktion och kunskapsutveckling» hvor forskerne gjør en kritisk tekstanalyse av svenske lærebøker for nybegynnere (Rostvall \& West, 2001). Studiene viser at lærebøkene i stor grad vektlegger

\footnotetext{
${ }^{1}$ Med lærebok menes i denne sammenhengen den fysiske boka som er beregnet på at elevene skal kunne kjøpe den og ta den med seg hjem.
} 
spilleteknikk og notekyndighet og i mindre grad gehørutvikling, skapende virksomhet og kritisk bevissthet.

\section{Et kritisk pedagogisk blikk}

Ei lærebok er en av mange læringsressurser som brukes i undervisning, og den er vanligvis en konkretisering av det som regnes som kunnskap i et fag og er metodisk tilrettelagt for en spesifikk målgruppe (tilpasset alder, institusjon og planverk). Også i kulturskolen er læreboka en viktig bestanddel i kunnskapsdannelsen i den sosiale og kulturelle konteksten som instrumentalundervisningen står i. Denne typen læringsressurs definerer i mange tilfeller hva det vil si å lære seg å spille et instrument, noe som giør det interessant å diskutere hvor mye definisjonsmakt læreboka kan og bør ha i denne typen undervisningskontekst.

I hvilken grad man kan si at en bok har makt, er selvsagt et spørsmål om hva man legger i maktbegrepet. I undervisningssammenheng er det relevant å se på makt som et relasjonelt begrep hvor samhandling og kommunikasjon danner tillærte måter å betrakte verden på, som igjen gir makt til de som behersker systemet. Freire beskriver makt på to måter: den typen makt som undertrykkeren har over den undertrykte $\mathrm{i}$ samfunnet, og makt som noe utdanningen kan bidra til å utvikle hos eleven: "[Lærerens] anstrengelser må være gjennomsyret av en dyptgående tillit til menneskene og deres skaperkraft» (Freire, 2011, s. 58). I musikkundervisningen antas eksempelvis læreren à kunne noe som gjennom undervisningen får betydning for måten eleven betrakter musikk som fenomen på. Læreren på sin side er en del av en undervisningsdiskurs som har uuttalte regler for hva som er «lov» og ikke innenfor diskursen, inkludert hva slags læringsmål som er viktige, hvordan man giør og forklarer ting, hva som er "en vanlig» spilletime og hvilke lærebøker man bruker. I ytterste konsekvens kan man også spørre seg om det er noe ved læreboka i seg selv som kan være undertrykkende. Kan læreboka og dens tilhørende diskurser ha en hemmende effekt på elevers ønske om å uttrykke seg kreativt gjennom musikk?

Forskjellige typer skriftlige framstillinger av faglig innhold kan ofte oppfattes som sannheten om et fag både for elev og lærer, ganske enkelt fordi det trykte ord (eller notebilde) framtrer som en autoritet i seg selv (Sanner, 2003). For å unngå fastlåste og mytebaserte «sannheter» er det viktig å holde i gang en kritisk bevisst dialog i fagmiljøene om den definisjonsmakten lærebøker kan ha. Definisjonsmakt handler blant annet om hva som regnes som kunnskap (Nerland, 2004) og hvordan dette settes i spill i læreren og elevens samhandling med de trykte bøkene. Mangel på kritisk bevissthet og debatt bidrar til å gi lærebøker mer makt. Lærebøker har i seg selv potensial til å stimulere til dialog og kritisk tenkning. Bøkene kan for eksempel gjennom oppgavetyper, musikkvalg, oppfordring til skapende virksomhet og undring bevisstgjøre elevene og giøre dem i stand til å bli «kritisk reflekterende og utvikle egen livskompetanse» (Rammeplan for kulturskolen s. 7). Kritisk bevisste lærere og elever er nødvendig for å unngå at lærebøker får funksjon av en slags «prefabrikert undervisning» (Hanken, 1998, s. 48). 
Målsettinger om stadig utvikling og forbedring av praksis, inkludert lærebøker, oppnås best gjennom kritisk bevisstgjøring av det bestående: det som man tar for gitt, og som man ofte ukritisk viderefører gjennom handling og ord. Freire (2011) sier at mennesker skaper og reflekterer i kontinuerlig interaksjon med omgivelsene, og i denne prosessen bevisstgjøres man de vedtatte sannhetene (som han kaller myter) og starter å stille spørsmål ved dem (Freire, 2011). Er det for eksempel slik at man må kunne spille «standardrepertoaret» for sitt instrument for å lykkes som musiker, eller at man må varme opp på instrumentet en halvtime hver dag? En oppvåknende kritisk bevissthet er i følge Freire en viktig betingelse for målsettinger om å frigjøre individet og endre diskursive maktstrukturer. Dette krever en likeverdig dialog hvor det felles målet er å endre seg selv og samfunnet gjennom handling. Hos Freire er ord handling, og uten handling er ordet dødt (Westrheim, 2004). I en musikkpedagogisk praksis vil dynamikken mellom måten man benevner verden/fenomener, og handlingene, påvirke hverandre ved at endring av tankesett/begrepsbruk fører til endring av praksis.

Kritisk pedagogikk i Freiretradisjonen er derfor opptatt av begrepsbruk og den makten som ligger i valg av ord. Freire (2011) sier at valg av ord har kraft i seg til å radikalt endre tankesett både hos lærer og elev, og det å sette nye ord på fenomener vil dermed også kunne være en endringskraft i seg selv. Teoretikere som Freire (2011), Darder (2015), Giroux (1993) og Greene (1988) oppfordrer til å endre ordene vi bruker om fenomener med det formål å endre undertrykkende praksis. Maxine Greene (1988) sier:

When people cannot name alternatives, imagine a better state of things, share with others a project of change, they are likely to remain anchored or submerged, even as they proudly assert their autonomy.

En målsetting om å endre noe, om enn bare litt, må dermed også innebære en bevisstgjøring knyttet til språket vi bruker. Det er altså heller ikke likegyldig hva vi kaller ting i en musikkpedagogisk sammenheng. Dette kan gjelde benevning av store eller små fenomener, alt fra om vi velger å kalle en firedelsnote for gånote eller firedel, til om vi kaller musikken til artisten Björk for rytmisk musikk eller verdensmusikk.

Som pedagog har jeg erfart at unge instrumentalelever sjelden er kritiske til lærebokas innhold, og at de har lett for å oppfatte læreboktekster som ubestridelige fakta. Dette kan forsterkes av at læreren ofte er engasjert i læreboka gjennom å peke i den, bruker den til å forme timen, gir lekser fra boka og veileder eleven i rett tolkning av det som står i boka (Rostvall \& West, 2001). Eleven blir opptatt av å finne ut hva læreren legger i teksten: "Man kan si at eleven søker lærerens tekst i leseteksten» (Nordkvelle, 2016, s. 278), for deretter å «sluke» innholdet: «[...] the reader would "eat up» the content of the author's text with the help of the "nutritionist teacher»» (Freire, 2005b, s. 58).

Dialogen er i følge Dysthe (2001) av avgjørende betydning for utvikling av kritisk bevissthet og en forutsetning for menneskets danning. Hun sier at dialogen som språklig foreteelse blir et metodisk og didaktisk element i forståelsen av samfunnet og muligheten til å bidra til å skape endring. Ei lærebok kan være et verktøy for dialog, 
samtidig som den konstituerer en form for dialog i seg selv. Det er derfor helt vesentlig å opprettholde en kontinuerlig diskusjon om hva slags kommunikasjon læreboka representerer og hvordan den inngår i forskjellige læringskontekster.

Jeg skal i det følgende gå nærmere inn på hvordan dimensjonene dialog, makt og kritisk bevissthet utspiller seg i de analyserte lærebøkene for instrumentalelever på begynnernivå.

\section{6 lærebøker i et kritisk pedagogisk lys}

De følgende betraktningene bygger på en innholdsanalyse (Krippendorff, 2004) av lærebøker beregnet på instrumentalundervisning med nybegynnere. Målet med analysen er å undersøke fenomenet instrumentallarebok i lys av kritisk pedagogikk i Freiretradisjonens forståelse av dialog, makt og utvikling av kritisk bevissthet. Det er bøkenes faglige innhold og oppgavetyper som har vært fokus for analysen.

\section{Data og metode}

I studien analyseres til sammen 26 lærebøker for nybegynnere på 15 forskjellige instrumenter (strykere, blåsere, slagverk, gitar og piano). Utvalget av bøker inkluderer de mest brukte lærebøkene i Norge. Jeg har hatt kontakt med to norske noteforlag hvor jeg fikk salgstall på de mest brukte bøkene i 2015 for de 15 vanligste instrumentene i kulturskolen. I tillegg kontaktet jeg til sammen 32 kulturskolelærere ved de største norske kulturskolene for å få innblikk i hvilke bøker som blir brukt i kulturskolene. Jeg undersøkte også nettsidene til forlagene for å se hvilke bøker de markedsfører. Dette resulterte i utvalget på 26 norske og svenske lærebøker. Begrunnelsen for utvalget er at analysen i størst mulig grad baseres på bøker som representerer undervisningsmateriell som brukes i kulturskolene i dag.

En kvalitativ innholdsanalyse er en forskningsmetode som har som mål å klassifisere tekster ${ }^{2}$ i analyserbare enheter (Cohen, Manion, Morrison \& Bell, 2011), og anses som en anvendelig forskningsteknikk «for making replicable and valid inferences from texts (or other meaningful matter) to the contexts of their use" (Krippendorff, 2004, s. 18). Innholdet i bøkene er kodet med utgangspunkt i det faglige innholdet og oppgavetyper og består av elementer som: bokas omfang, antall og type melodier, komponister, musikalsk materiale, hva som vektlegges i forord, progresjon, hvordan noter introduseres, sjangre, oppgavetyper (ut over selve melodiene), støttenotasjon, bildebruk, språkbruk, gehørøvelser og type musikkteori. Materialet er delt opp, organisert og kodet i kategorier i flere omganger for å avdekke mønstre og tendenser med fokus på hvordan dimensjonene dialog, makt og utvikling av kritisk bevissthet kommer til syne i det faglige innholdet og oppgavetypene i bøkene.

${ }^{2}$ I denne sammenheng benyttes et utvidet tekstbegrep som omfatter både bilder, musikk, lyd, tale m.m. i tillegg til skrift. 


\section{Innhold og oppgaver sett i lys av dialog, makt og kritisk bevissthet}

De aller fleste bøkene i utvalget er paperback-bøker i A4-format på ca. 70 sider. Bøkene er bygget opp av korte kapitler som presenterer noen få spilletekniske og notasjonsmessige konsepter, ofte presentert i små faktabokser, med tilhørende øvelser og melodier:
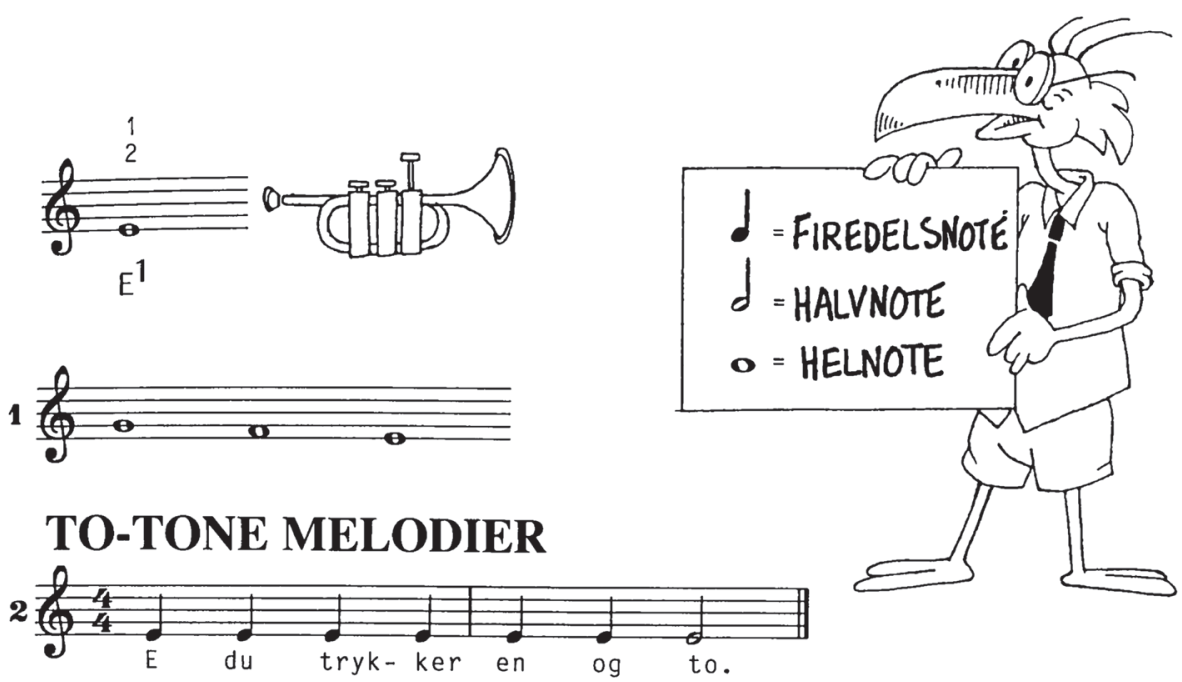

Illustrasjon: Fra Ture Trompet's første melodi-bok (Lindkvist, 1992).

I første del av bøkene får eleven enkle melodier som skal læres, i tillegg til noteleseoppgaver og tips om hvordan man bør stå/sitte når man spiller. Omfanget av det som skal læres er knyttet til det forfatterne oppfatter som oppnåelig i løpet av ca. ett år med undervisning. Dette omfatter eksempelvis 3-4 durtonearter (noen inkluderer én molltoneart), noteverdier inkludert 16-delsnoter, ambitus på omtrent én og en halv oktav, fenomener som fermate, repetisjonstegn, synkoper og 2-3 skalaer. Startpunkt og nivå er i denne sammenheng nokså instrumentavhengig.

Når det gjelder oppgavetyper, skiller Skjelbred et al. (2005) mellom åpne og lukkede oppgaver og mellom kontrolloppgaver, øveoppgaver og refleksjonsoppgaver i sin kartlegging av læremiddelpraksis. Analysen av oppgavetyper i instrumentallærebøkene, inkludert melodiene som skal spilles, viser at en stor andel av oppgavene vektlegger øve- og kontrolloppgaver (fakta, repetisjoner, regler) som i utgangspunktet er nokså lukkede og legger mindre vekt på åpne refleksjonsoppgaver. Bøkene representerer på denne måten en oppgavekultur som fremmer et empirisk kunnskapssyn (kunnskap som noe objektivt gitt og bygd på erfaring) (Dysthe, 1999) både når det gjelder selve formuleringene og måten oppgavene skal løses på. Det er sjelden man i disse bøkene ser oppgaver som er basert på en mer problemformulerende pedagogikk, som for eksempel: «Når du kan sangen godt, kan du prøve å lete fram melodien på fløyta di» (Krøger, 1996, s. 11). 
Oppgaver knyttet til gehørarbeid, definert som aktiviteter som stimulerer auditiv forståelse av musikk og musikalsk hukommelse, ser man også relativt lite av i bøkene. Den vanligste typen oppgaver knyttet til gehør går ut på å spille utenat melodiene man har lært/lest tidligere i boka, klappe rytmer, spille med akkompagnement og å synge melodiene før man spiller dem. En del bøker inneholder oppgaver hvor elevene skal synge en melodi og deretter prøve å spille den etter hukommelsen, eller improvisere en melodi sammen med et innspilt akkompagnement. Det er generelt sett svært få oppfordringer til å lytte til musikk eller skape egen musikk. Dette gir bøkene en nokså preskriptiv funksjon, særlig hvis læreren bruker dem som mal for undervisningstimene. I en kritisk pedagogisk praksis vil elevenes egne lytteerfaringer og lyttepreferanser utgjøre et svært sentralt utgangspunkt for dialog og samspill $\mathrm{i}$ instrumentalundervisningen. Lærebøkene i denne studien legger ikke eksplisitt opp til en slik dialog.

Freire er opptatt av at ferdigtygde «opplegg» hindrer elevenes forståelse av helheten i den praksisen de er en del av:

Ordrike undervisningstimer, krav til lesning, metoder for å vurdere «kunnskap», avstanden mellom lærer og opplært, kriteriene for å flyttes opp. Alt i denne ferdigsydde metoden tjener til å unngå å tenke.

(Freire, 2011, s. 60)

I mange av lærebøkene er oppgavene designet for at elevene skal kunne testes i hvorvidt de har lært seg den presenterte kunnskapen, og svært sjelden oppfordrer oppgavene til å være kreativt kritisk til innholdet i kapitlene. På denne måten legger mange av bøkene direkte eller indirekte opp til det Freire kaller Banking (sparebøssepedagogikk, påfyllingspedagogikk), noe som verken er kreativt eller frigjørende hvis bøkene brukes ukritisk kapittel for kapittel.

Noteskrift spiller en sentral rolle i alle lærebøkene i studien. Vi ser i hovedsak to retninger når det gjelder måten noter innføres på: På den ene siden benyttes innfallsvinkler hvor noteskriftens særtrekk styrer rekkefølgen og progresjonen på det som læres av musikk (først lærer man tre toner med tilhørende notasjon, og deretter spiller man musikk som består av de tre tonene). Notenes funksjon som notert klingende musikk refereres det da sjelden til. Den andre retningen er i større grad basert på at man spiller antatt kjente sanger, og så lærer man noteskrift knyttet til noen av elementene i sangene man spiller, noe som ligner mer på dagens skriftspråkundervisning (Blix, 2012). Denne innfallsvinkelen giør seg i hovedsak gjeldende i de nyeste lærebøkene i utvalget.

Analysen viser også at lærebøkene har få eller ingen oppfordringer til helhetlig forstålse for det musikalske notasjonssystemet og dets sammenheng med klingende musikk. Begreper som toneart, grunntone og taktart er så godt som fraværende, og dette gjelder også begrunnelser for de forskjellige notesymbolene (fermate, repetisjonstegn, styrkegrader etc.). Innholdet i lærebøkene er i stor grad fokusert på detaljer - uten oppfordringer til å reflektere over deres betydning i en musikalsk sammenheng. 
Ingen av de analyserte bøkene er utformet slik at de kan brukes som selvstudium. I tillegg viser analysen at mange av bøkene primært henvender seg til den voksne læreren, selv om de har et «barnevennlig» layout. Dette sees i de nokså kortfattede tekstene i bøkene, og det understrekes av flere av forfatterne i forordene at læreren må i tillegg bidra med råd og veiledning til den enkelte elev (Krøger, 1996). Dette gir læreren mye ansvar og makt, noe som krever bevisste og reflekterte lærere med gode kunnskaper om musikkpedagogikk i vid forstand.

I de nyeste lærebøkene ser man eksempler på at elevens egen livsverden tas på alvor og brukes som utgangspunkt for læring. De mer tradisjonelle bøkene har derimot en nokså strømlinjeformet progresjon uten noen dialog med elevens egne erfaringer og ønsker. Bøkene legger heller ikke opp til at eleven skal undre seg over hvorfor man gjør ting på gitte måter i timene. Et viktig spørsmål blir da hvordan læreren kan sikre at elevene reflekterer over om og hvorfor de har behov for å lære noter og hvilken rolle notene kan spille for læringen. Mange elever tror at man må kunne noter for å kunne lære seg å spille (Blix, 2012), noe lærebøkene har en tendens til å indirekte understøtte gjennom måten de er utformet på.

Det musikalske innholdet er nokså likt i mange av bøkene. Enkle melodier på 2-3 toner, ofte komponert av forfatteren selv, preger de første sidene i bøkene; deretter introduseres enkle barnesanger eller melodier elevene forventes å kjenne fra før. Sjangermessig dreier repertoaret seg i hovedsak rundt vestlige barnesanger, viser, folketoner, klassiske småstykker og noen poplåter. Dette bringer på bane en annen sentral problemstilling i et maktperspektiv, nemlig såkalt kanondannelse, altså utvalget av «tekster» man forholder seg til innenfor et fagfelt. Det er gjennom svært mange år etablert tradisjoner for hvordan man underviser på forskjellige instrumenter, og hva man underviser. Etter hvert etableres en kanon av musikk som «avspeiler samfunnets oppfatninger av seg selv, og som man ønsker å bevare» (Nordkvelle, 2016, s. 273). Dyrking av en bestemt gruppe komponister eller noen spesifikke musikkformer medfører at andre blir glemt og dermed ubevisst undertrykket. I analysen av instrumentallærebøker viste det seg for eksempel at en bestemt type melodier går igjen i en stor andel av bøkene.

Et dypere dykk inn i den musikalske kanon i de analyserte lærebøkene viser at omtrent ingen kvinnelige komponister er representert, bortsett fra i de tilfellene lærebokforfatteren er en kvinne som har skrevet de pedagogisk tilpassede melodiene i første halvdel av boka. Sjangermessig er det i hovedsak vestlige barnesanger, viser, enkle klassisk-romantiske stykker og enkle poplåter som preger bøkene.

Et annet forskningsfokus som framkommer i lærebokforskning de senere år, er representasjonen av kjønn og etnisitet i lærebøker (Rønningen, 2015). Det produseres mange lærebøker i dag hvor forfatterne virker forbausende lite bevisste på de mangfoldige bakgrunnene deres brukere har, og på muligheten bøkene har til å påvirke og endre stereotype oppfatninger av samfunnet og mennesker i stedet for å konservere dem. Det ligger en implisitt definisjonsmakt i å være den som skal velge ut et variert undervisningsmateriale som «treffer» mer enn én type elever, et ansvar 
som ligger både hos lærebokforfatteren og læreren. Hvis elev og lærer har snakket om hva som er målet med undervisningen (lære å spille, kose seg med musikk, bli flinkere musiker, lære å lese noter), kan det musikalske innholdet i større grad tilpasses den enkelte. Da blir ikke målet å spille «Blinke lille stjerne» eller bli ferdig med boka, men eksempelvis å bruke musikken til å lære seg å spille instrumentet og å uttrykke seg gjennom musikk.

Det er særlig i starten av undervisningen på et instrument at lærebøkene har etablert et typisk repertoar, og grunnen til dette ser ut til å være noen særtrekk ved melodiene som giør at de er egnet til å lære seg på mange forskjellige instrumenter. Mange av lærebøkene i studien argumenterer i forordet for at barna bør starte med musikk de kjenner, men det er vanskelig å se for seg at majoriteten av barn som starter på fløyte på kulturskolen kjenner til melodier som "Til Paris» eller «Mari har et lite lam». Det betyr selvsagt ikke at dette ikke er egnede melodier å bruke i undervisningen. For en lærer som møter en elev første gang, kan det likevel hende at det er viktigere å spørre hvilke melodier eleven faktisk kjenner og liker. Begrunnelser for utvalget av melodier i bøkene kan være alt fra vaner, etablerte sannheter, idiomatiske hensyn, notasjonsmessige hensyn og antakelser om hvem elevene er. Det er svært sjelden bøkene i seg selv oppfordrer elevene og læreren til å ta utgangspunkt i elevens preferanser og bakgrunn, noe som i et kritisk pedagogisk perspektiv representerer et hinder for en likeverdig dialog og anledning til kritisk refleksjon.

Språket i lærebøker er også en maktfaktor ved at det kan framstå som tilsynelatende nøytralt og samtidig «belærende», som om det som framstilles er udiskutable fakta og at forfatteren har selve svaret (Hanken, 1998). I lærebøkene i den foreliggende studien forklares musikalske fenomener på ganske forskjellige måter, og svært sjelden gis det refleksjoner rundt benevnelsene i bøkene. Eksempelvis har man begrepene notenavn og tonenavn som kan føre til misforståelse av notenes funksjon som nedskrevet lyd/musikk hvis boka eller læreren sier: «Spill disse notene», når man egentlig mener tonene. Altså: Notene er nedskrevne toner, og man spiller klingende toner, ikke noter. Elever vil kunne tolke «å spille noten A» som en trykkeinstruks i stedet for å tenke at noten representerer en klingende tone man skal spille. Det faktum at cirka en tredjedel av bøkene kalles instrumentalskoler ("Min første hornskole»), peker i seg selv på en slags påfyllingspedagogikk («banking») hvor man skal oppleres etter noen helhetlige prinsipper som er gitt på forhånd. Noen av bøkene heter «Melodiboka» eller «spillebok», noe som indikerer en åpnere pedagogisk retning.

Flere steder i bøkene møter man på språkbruk som er svært kortfattet/punktvis, noe som lett fører til misforståelser eller dårlig kommunikasion med brukerne av boka (Blix, 2012, s. 121). Freire (2005a) sier at begripelighet er en nødvendig forutsetning for dialog og kommunikasjon, og at uten språkmessig begripelighet i læringssituasjonen opprettholdes et skjevt maktforhold mellom den som forstår og den som ikke er inneforstått med referansene eller måten å uttrykke seg på. Sjargong, vage referanser og tvetydige måter å si ting på er alle former for reproduksjon av taus kultur $i$ undervisningssituasjoner: «[...] the verbal expression of one of the Subjects 
must be perceptible within a frame of reference that is meaningful to the other Subject» (Freire, 2005a, s. 125). I de analyserte lærebøkene ser vi mange tilfeller av kortfattede instruksjoner, forklaringer og symbolbruk som er både tvetydige og kontraintuitive og gir eleven liten mulighet til å finne ut av ting på egen hånd (Blix, 2012, s. 122).

De bøkene som selger best i følge forlagene, er de som ligner mest på hverandre. Det er antakelig vanskeligere å få solgt bøker som kommer med nyere konsepter, eller som trenger en del innsats for å sette seg inn i bokas pedagogiske grunntanker. Dette vil i prinsippet også styre hva slags bøker forlagene satser på, og dermed vil en viss markedsøkonomisk makt spille inn når det gjelder bøkenes grunnleggende kunnskaps- og læringssyn (Johnsen, 1993).

Sett i lys av det mangfoldet av muligheter man i dag har når det gjelder utvalg av innhold, didaktiske innfallsvinkler og utformingen læremidler kan gis, må man si at de 26 analyserte bøkene er overraskende konforme. Når det gjelder konkret musikkteoretisk innhold (noteverdier, tonaliteter, typer notetegn), repertoar, progresjon og måten stoffet framlegges på, er bøkene nokså ensartede. En mulig forklaring på dette kan være at bøkene i stor grad svarer til de undervisningsmetodene mange av lærerne som bruker dem selv erfarte som elever, og at bøkene på denne måten oppleves som trygge og fornuftige. Forskning på læremiddelbruk viser i tillegg at lærere generelt bruker lærebøker mer konservativt enn forfatterne har lagt opp til (Dahl, 1993; Skjelbred et al., 2005), men vi vet svært lite om hvorvidt dette gjelder bruk av lærebøker i musikk. Det krever mye innsats og endring i tankesett for å ta i bruk bøker som er annerledes og uvante, noe som i en hektisk hverdag kan være krevende for mange.

\section{Coda}

Tekster har i seg selv en form for autoritet i det vestlige samfunnet, og spesielt hvis de er utgitt på et anerkjent forlag. Det skrevne eller trykte ord tillegges ofte større status og troverdighet enn det sagte, og et trykt dokument oppfattes som noe man kan stole på (Blix, 2009; Ong, 2002). Lærebøker vil aldri være nøytrale kilder til kunnskap. Bøkene er skrevet av forfattere som alle har sine personlige, kulturelle og faglige interesser og meninger. Mer eller mindre eksplisitte verdisyn og tradisjoner framkommer i bøker i form av avklarende forord hvor vektlegging av innhold og aktiviteter beskrives. I tillegg ligger det implisitte verdisyn i måten lærebøker er utformet på, noe som kan representere et helt system av verdier, talemåter og tradisjoner som kan framstå som sannheter uten nødvendigvis å være det. Freiretradisjonens kritiske pedagogikk framhever dialogen som utgangspunkt for alle gode læringssituasjoner, og i dette ligger også en oppfordring til å endre maktforholdet mellom lærer/lærebok og elev slik at elevens stemme blir tydeligere.

De pedagogiske implikasjonene av en slik forskyving mot et større fokus på elevens egne erfaringer, mål og forståelser av musikk kan konkretiseres ved å gi eleven i 
oppgave å skrive «læreboka» selv gjennom egne notater, komposisjoner og forklaringer. Den trykte boka kan komme som et supplement til dette og være en del av dialogen hvor eleven kan ha et kritisk bevisst forhold til lærebøker sammen med læreren. Kritisk betyr da ikke skeptisk, men tenkende og kreativt undrende. En inngang til noteskrift kan være at eleven i en periode får i oppgave å skrive ned melodiene hun lærer på sin egen måte, og at den konvensjonelle noteskriften innføres i dialog med elevens symbolinnsikt. Lærerens innsikt i elevens bakgrunn og forståelser står da sentralt, og eleven vil kunne forholde seg vurderende og kritisk til konvensjonelle noters muligheter til å beskrive klingende musikk.

Det generelle inntrykket av de analyserte lærebøkene er først og fremst at de er laget av dyktige og kreative pedagoger med kjærlighet og engasjement for elevene og faget. Selv om det ikke uttrykkes eksplisitt i de fleste bøkene, ligger det en forventning om at elevene som kjøper bøkene har lærere med solid musikkpedagogisk kompetanse, som kan ta i bruk bøkene til eleven og fagets beste. Det er også viktig å påpeke at det er sjelden at denne typen lærebøker brukes uten tilleggsmateriell, og instrumentallærere supplerer ofte med egenproduserte opplegg, bruker digitale læringsressurser og annet læremateriell (Blix, 2012). En viktig oppfølgingsstudie vil derfor være å kartlegge hvordan lærebøker brukes i kulturskole- og privatundervisning på begynnernivå, for å få et reelt innblikk $\mathrm{i}$ hvorvidt det jobbes med dialogbasert, bevisstgjørende pedagogikk i denne undervisningskonteksten.

Læreboka er ofte elevens første møte med et fag, og boka vil utgjøre et sterkt element i elevens forståelse av hva faget er. Det er derfor god grunn til å være bevisst både hvilke læringsressurser man bruker og hvordan man bruker dem. I et kritisk pedagogisk perspektiv ser man på handlinger, rekkefølger, fortellinger og ordvalg som sterke premissleverandører for hva som er sant og virkelig, og elever i kulturskolen som lærer et kunstfag gjennom blant annet imitasjon og subjektiv tolkning av symboler og kroppsspråk, preges kontinuerlig av små og store handlinger, blikk og ord fra lærerens side. Reflekterte musikkpedagoger er opptatt av både ord og gjerning, og gjennom dette skapes gode forbilder. I dette landskapet spiller lærebøker og lærebokbruk en stor rolle. Vi som musikkpedagoger bør kunne analysere læringsressurser ut fra mer enn bare musikalsk innhold, teknikk og noteundervisning. Vi må engasjere oss i elevens utvikling av "estetisk, sosial og kulturell kompetanse» og "evne til kritisk refleksjon og selvstendige valg» (Rammeplanen for kulturskolen s. 8), og da må læringsressursene også analyseres ut fra spørsmål om læringssyn, verdier, kritisk tenkning, makt, bevisstgjøring og hva elevene og læreren gjennom bevisstgjørende dialog kan oppnå sammen.

\section{Forfatteromtale}

Hilde Synnøve Blix er dosent (ph.d.) i hørelære og musikkpedagogikk og ansatt på Musikkonservatoriet ved UiT - Norges arktiske universitet. Hun er utdannet musikkviter fra NTNU før hun tok sin ph.d. i musikkpedagogikk ved Norges 
musikkhøgskole. Hennes forskningsinteresser er knyttet til gehørutvikling, notelesing og læremidler. I tillegg har hun de seneste årene forsket på likestilling og kjønn i musikkfeltet. Hun var i 2006 redaktør for boka "Øre for musikk" (Unipub) og har senere publisert en rekke forskningsartikler og bøker nasjonalt og internasjonalt med tematikk som spenner fra gehørundervisning og notedidaktikk til likestilling og kunstnerisk utviklingsarbeid.

\section{Referanser}

Askeland, N., Maagerø, E., \& Aamotsbakken, B. (Red.). (2013). Lcereboka. Studier i ulike lareboktekster. Trondheim: Akademika forlag.

Blix, H. S. (2009): Det store skillet? Om skriftlighetens betydning for kognitiv bevissthet i musikalsk læring. I Nielsen, F. V., Holgersen, S. E., \& Nielsen, S. G. (Red.) Nordisk musikkpedagogisk forskning, 11, 69-91.

Blix, H. S. (2012). Gryende musikkliteracy. Unge instrumentalelevers tilegnelse av musikkliteracy $i$ et sosiokognitvt perspektiv (Doktoravhandling. Norges musikkhøgskole). Oslo: NMH-publikasjoner.

Cohen, L., Manion, L., Morrison, K., \& Bell, R. C. (2011). Research methods in education. London: Routledge.

Dahl, A. G. (1993). Oppgavekulturen $i$ den videregående skolen, studieretningen for handels- og kontorfag: et fagdidaktisk studium av oppgavens rolle og funksjon i undervisningen. Hønefoss: Høgskolen i Buskerud.

Darder, A. (2015). Freire and Education. New York: Routledge.

Dysthe O. (Red.). (2001). Dialog, samspel og lering. Oslo: Abstrakt Forlag.

Dysthe, O. (1999). Ulike perspektiver på kunnskap og læring. Bedre Skole 1999.

Freire, P. (2005a). Education for critical consciousness. New York: Sheed \& Ward.

Freire, P. (2005b). Teachers as Cultural Workers. Letters to Those Who Dare to Teach. Boulder, Colo: Westview Press. Freire, P. (2011). De undertryktes pedagogikk. (2. utg.). Oslo: Gyldendal Akademiske.

Fuglseth, K. (1994). Hornlerebøker - en analyse og vurdering (Hovedoppgave. Norges musikkhøgskole). Oslo: Norges musikkhøgskole.

Giroux, H. A. (1993). Paulo Freire and the Politics of Postcolonialism. I P. McLaren \& P. Leonard (Red.), Paulo Freire. A Critical Encounter (s. 177-188). London and New York: Routledge.

Greene, M. (1988). The dialectic of freedom. New York and London: Teachers College Press.

Hanken, I. M. (1998). Læreboken som kunnskapsformidler. I F. V. Nielsen, H. Jørgensen \& B. Olsson (Red.), Nordisk musikkpedagogisk forskning, 2, 47-58. Oslo: NMH-publikasjoner.

Hoffart, T. (1995). Analyse og sammenligning av gamle og nye cellolcerebøker. (Hovedoppgave. Universitetet i Oslo). Oslo: Universitetet i Oslo.

Johnsen, E. B. (1993). Textbooks in the Kaleidoscope. A Critical Survey of Literature and Research on Educational Texts. Oslo: Scandinavian University Press.

Juhl, G. K., Hontvedt, M. \& Skjelbred, D. (2010). Laremiddelforsking etter LK06. Eit Kunnskapsoversyn. Rapport 1/2010. Tønsberg: Høgskolen i Vestfold.

Krippendorff, K. (2004). Content analysis. An Introduction to Its Methodology. California: SAGE Publications.

Krøger, E. N. (1996). Min egen fløyteskole, Bok 1. Oslo: Norsk Musikforlag.

Lindkvist, J. (1992). Ture Trompet's første melodi-bok. Nybegynnerskole for trompet. Moholm: Notposten.

Nerland, M. (2004). Kunnskap i musikkpedagogisk praksis. I G. Johansen, S. Kalsnes, \& Ø. Varkøy (Red.), Musikkpedagogiske utfordringer. Artikler om musikkpedagogisk teori og praksis (s. 46-56). Oslo: Cappelen Akademisk Forlag.

Nordkvelle,Y.T. (2016). Lærebøker - påvirkning eller formidling? I O. Kvamme, T. Kvernbekk \& T. Strand (Red.), Pedagogiske fenomener - en innføring (s. 273-281). Oslo: Cappelen Damm Akademisk.

Nordlysdebatt: Kampen mellom lcereplanen og lereboka. https://uit.no/Content/393365/Læreboka\%20og\%20 læreplanen.pdf (hentet 05.01.18)

Ong, W. J. (2002). Orality and literacy: the technologizing of the word. London: Routledge.

Rammeplanen for kulturskolen - Mangfold og fordypning: http://www.kulturskoleradet.no/rammeplanseksjonen/ rammeplanen (hentet 05.01.18)

Rostvall, A.-L., \& West, T. (2001). Interaktion och kunskapsutveckling - en studie av frivillig musikundervisning (Doktoravhandling. Kungliga Musikhögskolan). Stockholm: KMH Förlaget.

Rønningen, A. (2015). Det etniske steget. En drøfting av kulturelt mangfold $i$ pedagogiske tekster for musikk for norsk ungdomsskole (Doktoravhandling. Norges musikkhøgskole). Oslo: NMH-publikasjoner. 
Sanner, G. K. (2003). Larebøker i musikk - en studie av to lereverk i musikk for ungdomstrinnet. Rapport 4/2003. Tønsberg: Høgskolen i Vestfold.

Selander, S. \& Skjelbred, D. (2004). Pedagogiske tekster for kommunikasjon og lering. Oslo: Universitetsforlaget. Skjelbred, D., Solstad, T. \& Aamotsbakken, B. (2005). Kartlegging av laremidler og laremiddelpraksis. Tønsberg: Høgskolen i Vestfold.

Skjelbred, D. \& Aamotsbakken, B. (Red.). (2010). Lesing av fagtekster som grunnleggende ferdighet. Oslo: Novus. Tønnesen, E. S. (2013). Læreboka som kunnskapsdesign. I N. Askeland, E. Maagerø, \& B. Aamotsbakken (Red.), Lareboka - studier i ulike lcereboktekster (s. 147-163). Trondheim: Akademika forlag.

Westrheim, K. (2004). Kritisk pedagogikk og multikulturalisme i lys av Freiretradisjonen. Noen sentrale perspektiv. Nordisk Pedagogikk, 24(3), 212-266.

Ødegård, L. O. (1995). "Hvor ble det av sangen i skolen?» En analyse av sang og sangbøker $i$ norsk skolehistorie (Hovedoppgave, Universitetet i Oslo). Oslo: Universitetet i Oslo.

The publication charges for this article have been funded by a grant from the publication fund of UiT The Arctic University of Norway 